\title{
Paradigma Tradisionalisme dan Rasionalisme Hukum dalam Perspektif Filsafat Ilmu
}

\author{
Abu Yasid \\ Fakultas Syariah IAI Ibrahimy Situbondo Jatim \\ Jl KHR Syamsul Arifin 1 Sukorejo Banyuputih Situbondo 68374 Jawa Timur \\ yazidabu@hotmail.com / er_rohmah@ymail.com
}

\begin{abstract}
Both Islamic law and western positivism have similarpretension related to the final aim in arranging the community according to the existing regulation. The stain of differences can not be avoided when the jurists are not in line with human as both subject and user in observing the relation pattern among the regulations themselves. The focused problem of this research is; first, how are the rational and traditional paradigms in the ideal tradition of Islamic law? Second, what are the rational and traditional paradigms in the ideal tradition of western law? Third, how is the implication of the difference of Islamic law and western positivism in the perspective of philosophy studies? This research is a qualitative research using a philosophic approach. The data collecting technique was conducted through the literacy study. This research has concluded as the following; first, a traditionalism group tends to keep the tradition that has been organized as the formal consideration in the law excavating activities. On the other hand, a rationalism group proposes the using of common sense that is often simply called into qiyas (analogy) in the series of istinbath law process. Second, according to the traditionalism view, deciding the law is in the normative and positivism (empiric) view which are always based on facts and empiric experiences, while rationalism view, the reality can be known or several truths about reality can be known without depending on the observation, experience, and the use of empiric method. Third, the difference is implied to the law relating to the social classes as its subject. If the law touches morality, so the law substance is not absolute and final, but it depends on the aspect of advantage as the source.
\end{abstract}

Key words: Rationalism, positivism, religious texts, normativism, traditionalism.

\begin{abstract}
Abstrak
Baik hukum Islam maupun positivisme barat mempunyai pretensi sama menyangkut tujuan akhirnya untuk menata masyarakat sesuai aturan hukum yang berlaku. Percikan perbedaan tak dapat dielakkan ketika para Juris tidak sebangun dalam melihat pola hubungan antara hukum itu sendiri dengan manusia sebagai subjek sekaligus user. Fokus masalah pada penelitian ini adalah; Pertama, bagaimana paradigma rasionalisme dan tradisionalisme dalam tradisi pemikiran hukum Islam? Kedua, bagaimana paradigma rasionalisme dan tradisionalisme dalam tradisi pemikiran hukum barat? Ketiga, bagaimana implikasi perbedaan antara hukum Islam dan positivisme barat dalam perspektif filsafat ilmu? Penelitian ini bersifat kualitatif dengan pendekatan filosofis. Teknik pengumpulan data dilakukan dengan cara studi kepustakaan. Penelitian ini menyimpulkan, Pertama, kalangan tradisionalisme cenderung mempertahankan tradisi yang sudah melembaga menjadi acuan formal dalam aktivitas penggalian hukum. Sebaliknya, kalangan rasionalisme mengedepankan penggunaan akal-budi yang saat itu sering disimplifikasi menjadi qiyas (analogi) dalam rangkaian proses istinbath hukum. Kedua, menurut pandangan tradisionalisme menentukan ketentuan hukum pada pandangan normatif dan positivisme (empirisme) yang selalu bertumpu pada fakta dan pengalaman empirik, sedangkan pandangan rasionalisme, realitas dapat diketahui atau beberapa kebenaran tentang realitas dapat diketahui tanpa bergantung pada pengamatan, pengalaman, dan penggunaan metode empiris. Ketiga, perbedaan tersebut berimplikasi pada kaitan hukum dengan pranata sosial sebagai subjeknya. Jika hukum bersentuhan dengan moralitas maka substansi hukum tidak bersifat absolut dan final melainkan bergantung pada aspek kemaslahatan sebagai muaranya.
\end{abstract}

Kata kunci : Rasionalisme, positivisme, teks wahyu, normativisme, tradisionalisme. 


\section{Pendahuluan}

Hukum dengan beragam madzhab pemikiran di dalamnya bertujuan untuk mengantarkan ummat manusia menuju kehidupannya yang bermashlahah dan berkeadilan. Dalam Ilmu Hukum Islam, tujuan hukum semacam ini dikenal dengan sebutan maqashidus syari'ah, yakni tujuan akhir disyari'atkannya Islam. Dengan tujuan seperti ini maka dalam pembahasan hukum, unsur "manusia" menjadi sangat strategis sebagai sasaran untuk diperhatikan aspek kebahagiaannya baik di dunia maupun di akhirat. Lantaran manusia hidup dalam sebuah ruang komunitas dan lingkungan yang sangat dinamis maka proses pembentukan hukum pun mengalami eskalasi perkembangan cukup pesat, bahkan cenderung berskala sangat progresif.

Dalam konteks inilah munculnya madzhab-madzhab pemikiran hukum tak dapat dielakkan. Dalam hukum Islam lahir pemikiran madzhab ahlur ra'yi (rasionalis), ahlul hadith (tradisionalis) dan al-jami' bainahuma (moderat). Dalam sejarah pemikiran hukum barat demikian juga halnya, muncul beberapa school of thought, misalnya kalangan positivisme, rasionalisme, dan normativisme dengan berbagai sub-sub madzhab lagi di dalamnya. Diferensiasi aliran hukum seperti ini selain bisa disebut alamiyah juga tidak bisa lepas dari hasil pengamatan para Juris menyangkut pengelompokan ilmu hukum itu sendiri menurut perspektif filsafat ilmu.

Teks wahyu turun bukan dalam ruang yang kosong, melainkan beriringan dengan konteks realitas yang terus berkembang dan bergerak dinamis. Persinggungan teks wahyu dengan realitas masyarakat, dengan demikian, memiliki maknanya tersendiri dalam memunculkan postulat-postulat hukum. Integrasi teks dan konteks ini perlu dielaborasi secara sistematik karena sejatinya hukum tuhan tidak lahir kecuali untuk konteks kesejahteraan dan kemaslahatan ummat manusia sepanjang sejarahnya. Teks dan konteks mempunyai hubungan komplementer dalam proses pergulatan pencarian wujud kemaslahatan dan kesejahteraan ummat manusia sebagai ending atau tujuan akhir dari seluruh rangkaian proses pembentukan hukum.

Beragam madzhab pemikiran hukum tentunya mempunyai persepsi relatif sebangun menyangkut tujuan akhir pembentukan hukum. Problem akademik yang kemudian muncul, percikan diferensiasi pendapat sering mengemuka lantaran mereka tidak sama dalam melihat pola hubungan antara hukum itu sendiri dengan manusia sebagai subjeknya. Sebagian kalangan berpandangan bahwa hukum bukanlah institusi yang absolut dan final melainkan bergantung pada manusia 
sebagai user. Dalam konteks ini, hukum sangat ditentukan oleh pertanyaan bagaimana manusia melihat dan menggunakannya. Pada kenyataannya, beragam teori hukum yang berkembang selama ini bertumpu kepada kedua faktor ini.

Oleh karena itu, jika bandul sebuah teori hukum bergeser ke arah manusia maka teori tersebut memberikan ruang cukup banyak pada faktor manusia. Sebaliknya jika bandul teori tadi banyak bergeser ke arah hukum maka teori tersebut akan menganggap hukum sebagai sesuatu yang mutlak, otonom, dan final. Pengkutuban kedua teori hukum ini pada gilirannya sangat berimplikasi pada lahirnya sejumlah aliran hukum dengan berbagai jenis dan karakternya, mulai dari yang normatif-tradisionalis, empirispositivistik sampai aliran hukum yang bercorak liberal-rasionalis.

Dalam konteks tersebut, penelitian ini akan membahas pengkutuban dua mainstream aliran hukum, yaitu antara rasionalisme dan tradisionalisme yang terjadi dalam bingkai pemikiran hukum Islam dan antara rasionalisme, positivisme, dan normativisme dalam tradisi pemikiran positivisme barat. Selain itu, penelitian ini juga menyorot soal implikasi konkret dari gejala terjadinya perbedaan pandangan antara hukum Islam dan positivisme barat menurut perspektif filsafat ilmu. Tujuan bahasan dalam tulisan ini tak lain untuk menemukan hasil verifikasi hukum dari beragam aliran tadi menurut perspektif filsafat ilmu.

\section{Rumusan Masalah}

Pertama, bagaimana paradigma rasionalisme dan tradisionalisme dalam tradisi pemikiran hukum Islam? Kedua, bagaimana paradigma rasionalisme dan tradisionalisme dalam tradisi pemikiran hukum barat? Ketiga, bagaimana implikasi perbedaan antara hukum Islam dan positivisme barat dalam perspektif filsafat ilmu?

\section{Tujuan Penelitian}

Pertama, untuk mendeskripsikan gejala kemunculan madzhab rasionalisme dan tradisionalisme dalam tradisi pemikiran hukum Islam. Kedua, untuk mendeskripsikan gejala kemunculan madzhab rasionalisme dan tradisionalisme dalam sistem hukum positivisme barat. Ketiga, untuk mendeskripsikan implikasi konkret dari gejala terjadinya perbedaan pandangan antara hukum Islam dan positivisme barat menyangkut pengkutuban madzhab-madzhab pemikiran hukum menurut perspektif filsafat ilmu. 


\section{Metode Penelitian}

Penelitian ini merupakan penelitian normatif karena data-data yang diperlukan mempunyai latar alami, bersifat deskriptif serta lebih mempertimbangkan proses ketimbang hasil. Teknik pengumpulan data dilakukan dengan library research (penelitian kepustakaan). Buku-buku literatur yang terkait dengan tema penelitian merupakan subyek yang dikumpulkan dengan menggunakan pola snowball sampling. Artinya, informasi yang diterima melalui subyek berupa buku literatur dapat berkembang ke literatur-literatur lain dalam skala pembahasan lebih intens hingga mencapai titik jenuh.

Jenis data yang digunakan dalam penelitian ini adalah data primer yang merupakan bahan hukum sekunder, yaitu fenomena sosial kemasyarakatan dengan perangkat hukumnya sebagai preskripsi. Sumber data yang digali berupa dokumen kepustakaan (paper) dan situasi atau suasana yang melingkupi (place). Sumber data dokumen terdiri dari buku referensi beserta dokumen-dokumen penting lainnya yang bertalian dengan topik hukum. Sedangkan sumber data yang berupa suasana atau tempat tak lain adalah situasi kultural masyarakat sebagai obyek hukum. Teknik pengumpulan data yang dilakukan dalam penelitian ini adalah dokumentasi. Dengan teknik ini, penelitian dilakukan dengan menyelidiki benda-benda tertulis berupa buku-buku referensi, naskahnaskah peraturan dan perundang-undangan, serta dokumen-dokumen lain yang ada relevansinya dengan pembahasan tentang hukum Islam dan positivisme barat.

Analisis data dilakukan dengan mengorganisasikannya, memilah-milahnya serta mengurutkannya sehingga menemukan pola, kategori dan satuan uraian. Data-data menyangkut madzhab tradisionalisme dan rasionalisme baik dalam bingkai hukum Islam maupun positivisme barat diklasifikasi dan dianalisis dengan menggunakan perangkat metodologi hukum. Analisis terhadap data-data kwalitatif-deskriptif dalam penelitian ini tidak dilakukan dengan menunggu data terkumpul secara keseluruhan. Sebaliknya, analisis data mulai dilakukan bersamaan dengan proses pengumpulan data. Analisis secara lebih intensif dan ekstensif dilakukan setelah semua data penelitian terkumpul. Dalam proses analisis juga dilakukan langkah reduksi sehingga data bisa disimplifikasi dan dipusatkan pada titik persoalan tertentu dan tidak melebar.

Agar data penelitian dapat lebih menjamin aspek akuntabilitas maka dalam penelitian ini perlu dilakukan pengecekan ulang, baik dalam bentuk triangulasi maupun peer debriefing. Triangulasi dimaksudkan untuk mengecek kembali sumber 
data dengan membandingkannya dengan berbagai sumber lain. Begitu juga metode pengumpulan data yang satu dibandinkan dengan metode lain dalam topik yang sama. Peer debriefing dilakukan untuk memberi kesempatan kepada para kolega sesama dosen untuk ikut memperkaya dan mengkritisi data-data yang telah dihimpun dalam proses penelitian ini. Dengan langkah ini maka peneliti bisa mendapatkan masukan berkaitan dengan bagaimana cara memperoleh informasi akurat, kelayakan informasi, maupun hal-hal lain yang perlu diapresiasi.

\section{Hasil dan Pembahasan}

Munculnya beragam aliran hukum baik dalam bingkai pemikiran hukum Islam maupun pemikiran hukum barat banyak dipengaruhi oleh iklim sosial di mana dan kapan pemikiran hukum tersebut tumbuh dan berkembang. Pada prinsipnya, hukum dikreasi bukan untuk dirinya sendiri melainkan untuk menebar kemaslahatan dan keadilan di tingkat realitas masyarakat. Namun demikian, untuk mengukur kadar kemaslahatan di tengah realitas yang teruas bergerak dinamis, perangkat analisis serta sumber-sumber hukum yang dipergunakan seringkali menyebabkan terjadinya gesekan konsep hukum yang kemudian memunculkan beberapa madzhab dan aliran dengan beberapa karakteristik yang dimiliki. Dalam pembahasan ini akan diketengahkan tiga persoalan menyangkut gejala munculnya madzhab-madzgab pemikiran hukum serta implikasinya pada realitas masyaratkat terus berkembang seiring perputaran waktu. Ketiga pembahasan tersebut meliputi, (1) Rasionalisme dan Tradisionalisme hukum Islam, (2) Positivisme, Normativisme dan Rasionalisme hukum barat, dan (3) Implikasi perbedaan antara hukum Islam dan positivisme barat dalam perspektif filsafat ilmu.

\section{Rasionalisme dan Tradisionalisme Hukum Islam}

Sejak awal perkembangannya, hukum Islam merupakan suatu kekuatan dan sumber motivasi kreatif-dinamis untuk mengkreasi aturan yang mengikat bagi perjalanan ummat manusia. Munculnya sejumlah aliran hukum Islam yang mempunyai corak beraneka ragam sesuai dengan latar belakang sosio-kultural di mana aliran itu tumbuh dan berkembang menunjukkan kecenderungan di atas. Pada mulanya, hukum Islam lahir secara natural di bawah bimbingan wahyu yang diemban langsung oleh Rasulullah SAW. Begitu pula pada era sahabat dan tabi'in, hukum Islam tumbuh dan berkembang secara alamiah melalui instink dan naluri 
mereka dalam menyerap kalam Ilahi maupun sabda Nabi. Praktis pada kurun-kurun ini kelahiran hukum Islam tidak dilatari oleh perdebatan sengit di antara para Juris Islam baik dari kalangan Sahabat maupun Tabi'in.

Baru pada era tabi' al-tabi'in, tepatnya pada abad kedua Hijriyah, hukum Islam mengalami perkembangan pesat seiring perluasan wilayah Islam dan ranah penerapan hukum sebagai pengejawantahan wahyu Tuhan. Jika pada dua kurun sebelumnya hukum Islam lahir secara natural melalui bimbingan wahyu maka pada kurun ini kelahiran hukum Islam tidak lepas dari kegelisahan akademik yang kemudian memunculkan paradigma hukum rasionalis (ahlur ra'yi) di satu pihak dan paradigma hukum tradisionalis (ahl al-hadith) di pihak lain. Kenyataan seperti ini sesungguhnya dilatari oleh semakin jauhnya bentangan jarak antara masa pewahyuan dengan realitas masyarakat yang kian berkembang. ${ }^{1}$

Sumber wahyu dalam bentuk teks agama, baik al-Qur'an maupun al-Hadits, telah berhenti turun sepeninggal Rasulullah SAW. Sementara itu realitas masyarakat terus bergerak dinamis seiring perputaran zaman. Dalam menyikapi persoalan seperti ini setengah pihak ada yang mengedepankan penggunaan akal-budi manusia yang saat itu sering disimplifikasi menjadi qiyas (analogi). Pengikut pola pendekatan seperti ini kemudian lazim disebut dengan kalangan rasionalis (ahl al-ra'yi). Di lain pihak, tidak sedikit mereka mempertahankan tradisi yang sudah melembaga menjadi acuan formal dalam aktivitas penggalian (istinbath) hukum. Pengikut pola pendekatan seperti ini lazim disebut dengan kalangan tradisionalis (ahl al-hadith).

Kalangan tradisionalis seringkali dinisbatkan pada ketokohan Imam Malik bin Anas (w. $179 \mathrm{H}$ ) yang berpusat di Hijaz, sementara kalangan rasionalis diwakili oleh Imam Abu Hanifah (w. 150 H) di Baghdad. Jika Imam Malik sangat terikat dengan fatwafatwa sahabat dan tradisi-tradisi penduduk Madinah dalam aktivitas istinbath hukumnya, maka Imam Abu Hanifah yang hidup di kota yang tergolong metropolitan pada saat itu sangat rasional dan sangat selektif dalam memilih dan memilah hadith-hadith yang dapat digunakan sebagai pijakan hukum. Oleh karena itu, dalam aktivitas istinbath hukumnya beliau lebih sering menggunakan analogi (qiyas) dibanding teks hadith yang masih diperdebatkan kesahihannya.

Kelahiran metodologi hukum Islam tidak lepas dari kegelisahan akademik yang kemudian memunculkan pengutuban dua paradigma pemikiran di atas, yakni

${ }^{1}$ Abu Yasid, Memahami Jurisprudensi Islam sebagai Mekanisme Istinbath Hukum, artikel dalam Jurnal AKADEMIKA, Program Pascasarjana IAIN Sunan Ampel Surabaya, Vol. 17 No. 1 September 2005, hlm. 184. 
paradigma rasionalisme dan tradisionalisme. Adalah Imam al-Syafi'i (w. 204 H) yang kemudian mencermati secara mendalam latar perdebatan pemikiran kedua belah pihak tersebut. Pada satu pihak al-Syafi'i berguru pada tokoh-tokoh aliran tradisionalisme di Makkah sebelum merantau ke Madinah untuk belajar fiqh pada Imam Malik. Pada pihak lain pengembaraan ilmiah beliau juga dilanjutkan ke Iraq untuk berguru pada tokoh-tokoh rasional seperti Imam Abu Hanifah dan Muhammad bin al-Hasan (w. 189 H). ${ }^{2}$ Dengan modal rihlah ilmiyah seperti ini, alSyafi'i lalu dapat memadukan penggunaan sumber ajaran suci yang berupa teks dengan kemampuan rasio secara bersamaan. Di satu pihak, beliau amat menghormati penggunaan al-Sunnah sebagai sumber inspirasi hukum. Di pihak lain, beliau juga tidak dapat menafikan begitu saja pentingnya penggunaan analogi dalam penetapan hukum-hukum syar'i. ${ }^{3}$

Pengamatan yang komprehensif terhadap kedua aliran pemikiran di atas kemudian mendorong al-Syafi'i untuk meletakkan dasar-dasar metode istinbath hukum seperti tercermin dalam master piece-nya, al-Risalah. ${ }^{4}$ Dengan terbangunnya metodologi hukum Islam ini, perdebatan sengit antara kedua aliran pemikiran di atas menjadi berkurang, atau bahkan sirna sama sekali, lantaran satu sama lain kemudian saling memahami hakikat perbedaan serta dapat merujuk semua aspek perbedaannya pada dasar-dasar istinbath yang sudah dibangun dan dibukukan oleh al-Syafi' $1 .{ }^{5}$ Peran al-Syafi'i memediasi kalangan rasionalis dan tradisionalis ini cukup memberikan andil dalam perkembangan pemikiran hukum Islam sampai saat ini. Tak kurang dari tokoh semisal Mohammad Arkoun, Pemikir Islam kelahiran Aljazair, pernah menandaskan bahwa pasca kelahiran rumusan metodologi hukum Islam oleh al-Syafi'i, wilayah agama yang semula thinkable (dapat terpikirkan) menjadi unthinkable (tak dapat dipikirkan). ${ }^{6}$

Embrio penyekatan ahlur ra'yi - ahlul hadith sesungguhnya mulai tumbuh sejak era sahabat walaupun dengan kadar intensitas berbeda dibanding pada era tabi' al-

${ }^{2}$ Lihat: Mushthafa Sa‘id al-Khinn, Dirasah Tarikhiyyah li al-Fiqh wa Ushulibi wa al-Ittijahat allati Dhaharat fiha, alSyirkah al-Muttahidah li al-Tawzi‘, Damaskus, 1984., hlm. 85 - 86; Muhammad Adib Shalih, Tafsir al-Nushush fi alFiqh al-Islami, al-Maktab al-Islami, Beirut, 1993, Juz I, hlm. 92 - 95; 'Abd al-Wahhab Ibrahim Abu Sulayman, al-Fiker al-Ushuli Dirasab Tabliliyyah Naqdiyyah, Dar al-Syuruq, Jeddah, 1984, hlm. 68 - 69.

${ }^{3}$ Noel J. Coulson, Conflicts and Tensions in Islamic Jurisprudence, The University of Chicago Press, USA, 1969, hlm. 6.

${ }^{4}$ Dalam karyanya ini, al-Syafi'i menekankan pentingnya kajian linguistik sebagai metode memahami sumbersumber hukum. Lihat Ahwan fanani, Ushul fiqh versus Hermeneutika tentang Pengembangan Pemikiran Hukum Islam Kontemporer, artikel dalam Jurnal ISLAMICA, Program Pascasarjana IAIN Sunan Ampel Surabaya, Vol. 4, No. 2, Maret 2010, hlm. $196-197$.

${ }^{5}$ Abd al-Wahhab Ibrahim Abu Sulayman, Loc. Cit.

${ }^{6}$ Mohammed Arkoun, Rethinking Islam Today, dalam edisi Indonesia, Islam Kontemporer: Menuju Dialog Antar Agama, Pustaka Pelajar, Yogyakarta, 2001, hlm. xiii. 
tabi'in yang ditandai dengan kemunculan madzhab-madzhab besar dalam ilmu fiqh. Umar bin al-Khatthab RA., misalnya, lebih mengedepankan pengamatan realitas sosial ketimbang formalitas teks ajaran. Ide pembukuan al-Qur'an, tidak memberi bagian zakat mu'allaf, enggan menjatuhkan hukuman potong tangan dan contoh-contoh sejenisnya dapat ditangkap sebagai cermin pemikiran sahabat Umar yang menganut pola rasionalisme. Sahabat Abdullah Ibnu Umar RA dalam batas-batas tertentu dapat merepresentasikan pola pemikiran seperti ini. Di lain pihak, pola pemikiran tradisionalisme juga menjadi trade mark para sahabat yang lain seperti Abu Bakar alShiddiq RA, Abdullah Ibnu Mas'ud RA dan lain-lain. Pada fase berikutnya, tabi'in, kubu pemikiran rasionalisme diwakili oleh 'Alqamah al-Nakha'i di Irak, sedangkan kubu tradisionalisme direpresentasikan oleh Sa'id bin al-Musayyab di Madinah.

Pada kenyataannya, tidak semua penganut pola pemikiran rasionalisme dengan serta merta mengabaikan formalitas teks, sebagaimana juga bukan berarti penganut kubu pemikiran tradisionalisme menafikan begitu saja aspek nalar dalam mengamati realitas. Apa yang sesungguhnya membedakan kedua pola pemikiran di atas adalah segmentasi dominan dalam mengapresiasi teks dan mentransformasi nilai ajaran terhadap realitas yang dihadapi. Jika pola pemikiran rasionalisme lebih banyak bergumul dengan aspek realitas secara fisik maka pola pemikiran tradisionalisme lebih berwawasan formal-metafisik dalam menyikapi keberadaan teks. Dengan demikian, penyekatan seperti di atas sesungguhnya dalam batas-batas tertentu dapat dianggap simplifikasi yang sangat personal lantaran substansi ajaran suci sendiri tidaklah mengenal penyekatan seperti itu. Inti ajaran suci sesunguhnya dapat memadukan keduanya dalam konteksnya yang bersifat komplementer, satu sama lain dapat saling melengkapi secara proporsional.

Dalam segmen ajaran esoteris-ketuhanan (ilahiyyah), apresiasi ajaran sangat literal dan tradisional karena berhadap-hadapan dengan otoritas Tuhan penguasa jagad raya. Semua teks yang berdimensikan ketuhanan tidak banyak memerlukan perangkat tafsir metafora secara progresif. Sebaliknya, domain ketuhanan cukup memerlukan penghayatan mendalam dalam wujud iman dan berserah diri. Dalam kaitan ini Rasulullah pernah bersabda:

\section{تفكروا في خلق الله ولا تفكروا في ذاته}

Artinya: Berpikirlah kamu tentang ciptaan Allah dan janganlah sekali-kali berpikir tentang dzat-NYA. ${ }^{7}$

${ }^{7}$ Sulaiman bin Ahmad bin Ayyub al-Thabrani, al-Mu'jam al-Kabir, al-Maktabah al-Syamilah, Ishdar 3.28., Juz II, hlm. 313. 
Bukan berarti domain ilahiyyah tidak dapat memantulkan nilai-nilai kemanusiaan yang eksoteris. Justru perangai manusia di muka bumi ini bisa dikatakan sangat bergantung bahkan sangat bertitik tolak pada sistem keimanan yang dilestarikan oleh setiap individu. Sebabitu, betapapun pembacaan teks ketuhanan bergerak secara vertikal dan literal namun ia dapat merefleksikan pula nilai-nilai horizontal kemanusiaan. Hanya, karena formalitas pembagian wilayah, teks agama yang bersentuhan dengan persoalan ketuhanan cenderung diapresiasi secara apa adanya. Padahal hakekatnya, masalah ketuhanan ini tidak mengabaikan dimensi akal-budi manusia begitu saja, khususnya ketika seorang hamba ingin mencari wujud Tuhan sang pencipta. Dalam literatur ilmu kalam sendiri mengimani wujud Tuhan mempunyai ketetapan hukum wajib aqli (wajib secara nalar), bukan wajib naqli (wajib berdasarkan teks). Implikasinya, seseorang dapat mengimani wujud penciptanya melalui pembuktian empirik dengan mengetengahkan dalil-dalil aksioma bahwa jagad raya ini mesti ada penciptanya yang maha tunggal. Nalar dan teks dalam Islam tidak dapat ditangkap sebagai dua hal yang berhadap-hadapan. Sebaliknya, keduanya memiliki hubungan komplementer menuju harmonisasi penataan sosial ummat yang berdimensikan keadilan universal.

Bagaimanapun juga ruang nalar dalam teks ketuhanan memang tidak sebesar dan selonggar dalam teks yang berdimensikan kemanusiaan (insaniyyah). Jika dalam segmen ketuhanan gerak nalar berkisar pada tataran ontologis dan filosofis maka dalam segmen eksoteris-kemanusiaan langgam nalar bergerak lebih eskalatif menuju realitas yang terus bergerak dinamis. Dalam konteks ini, penelitian hukum mempunyai peran sangat sentral untuk menghubungkan teks wahyu yang esoteris dan sakral dengan konteks kehidupan manusia yang eksoteris dan profan.

Betapa pun teks wahyu bersifat sakral dan mempunyai nilai kebenaran absolut, tetapi tanpa ditransmisikan maknanya kepada konteks kehidupan maka ia tidak akan berfungsi maksimal sebagai petunjuk Tuhan kepada manusia (hudan linnas). Karena itu dalam teks suci sendiri tidak terkirakan jumlahnya ayat-ayat yang menganjurkan kita melakukan penelitian, menggunakan nalar, merenung aneka ciptaan Tuhan, dan lain-lain.

\section{Positivisme, Normativisme, dan Rasionalisme Hukum Barat}

Filsafat ilmu membedakan pengetahuan berdasarkan dua sudut pandang, yaitu pandangan positivistik yang melahirkan ilmu empiris dan pandangan normatif 
yang melahirkan ilmu normatif. Ilmu hukum memiliki dua sisi yang dimaksud. Pada satu sisi ilmu hukum menampilkan karakter khas sebagai ilmu normatif, sementara pada sisi lain ia menunjukkan ciri-ciri sebagai ilmu empiris. Sisi empiris telah berkembang sedemikian rupa dengan menggunakan metode penelitian sosial. Karena itu, tanpa ragu orang memasukkannya dalam kerabat ilmu sosial. Bahkan sebagian pakar menggolongkan ilmu hukum sebagai ilmu sosial paling tua. Konsekuensi memasukkan ilmu hukum dalam ilmu sosial adalah penggunaan format ilmu sosial sebagai ilmu empiris dalam kegiatan penelitian hukum. Istilahistilah seperti sumber data, teknik pengumpulan data, analisis data, serta perumusan masalah dalam kalimat tanya adalah bermakna empiris. ${ }^{8}$

Secara diametral dapat dihadap-hadapkan antara ilmu hukum empiris yang melahirkan positivisme hukum pada satu pihak dan ilmu hukum normatif pada pihak lain. Positivisme hukum (Ilmu Hukum Empiris) memandang hukum sebagai sebuah fakta yang dapat diterapkan dan bebas nilai (value free). Namun, jika dihadapkan pada kenyataan kebutuhan para praktisi dan ilmuwan hukum normatif dalam praktik hukum sehari-hari, positivis hukum tidak dapat memberikan jawaban yang memuaskan terhadap pertanyaan sebagai batu uji kritis yang diajukan padanya, seperti “Apakah arti hukum empiris untuk praktik hukum tidak bermanfaat?". Studistudi sosio-legal menekankan arti penting penempatan hukum dalam konteks sosialnya, namun studi-studi tersebut hanya sampai pada tingkatan menggambarkan kesenjangan, tetapi jarang menjelaskannya. ${ }^{9}$

Diakui bahwa positivisme hukum dapat memberikan penjelasan yang bermakna tentang suatu gejala hukum yang diinterpretasi secara faktual, tetapi refleksi masa depannya hanya bermakna terhadap penyusunan kebijakan hukum dan aturan perundang-undangan yang akan datang dan tidak bermakna terhadap suatu problema atau kasus hukum yang sementara berlangsung dan harus diputuskan segera. Justru dalam hal ini penilaian kritis tentang isi hukum terletak dalam sifat khas hukum sebagai ilmu normatif dan ini tidak dapat dilakukan melalui ilmu empiris, karena ilmu empiris tidak membahas dimensi hakiki hukum itu sendiri. ${ }^{10}$

Perbedaan paradigma dan konsekuensi penggunaan metodologi dalam penelitian menunjukkan bahwa pandangan positivistik (ilmu hukum empiris)

\footnotetext{
${ }^{8}$ Johnny Ibrahim, Teori \& Metodologi Penelitian Hukum Normatif, Bayumedia Publishing, Malang, 2006, hlm. $123-124$.

${ }^{9}$ Ibid., hlm. $124-125$.

${ }^{10}$ Ibid.
} 
dibangun berdasarkan kriteria keilmuan, tradisi, dan prinsip-prinsip dalam ilmu sosial yang sangat kuat dipengaruhi oleh filsafat positivistik Auguste Comte. Dalam paradigma penelitian sosial, untuk menjaga kemurnian penelitian, posisi peneliti sebagai subjek yang mengamati objek penelitian. Peneliti bertindak sebagai pengamat yang memperhatikan objek penelitiannya dari luar. Dengan semua kemampuan pancaindranya ia membuat catatan terhadap apa yang terjadi pada objek yang diteliti serta membuat kesimpulan terhadap hasil pengamatannya. ${ }^{11}$

Filsafat positivistik Comte berakar amat kuat dalam paradigma pandangan seperti di atas. Hal ini ditunjukkan dengan munculnya pengaruh yang kuat dalam memandang ilmu hukum dari sisi empirisnya. Pandangan seperti ini banyak mengilhami gagasan American Realism serta ilmuwan-ilmuwan hukum empiris lain di belahan dunia. ${ }^{12}$

Manfaat temuan ilmu hukum empiris berguna dalam penyusunan kebijakan terhadap penegakan hukum dalam jangka panjang. Sebaliknya, ia tidak bermanfaat dalam praktik kasus hukum yang dihadapi pada saat sekarang. Dalam praktiknya, setiap keputusan hukum dibuat berdasarkan analisis hukum yang cermat dan akurat dengan menggunakan bahan-bahan hukum otoritatif yang sepenuhnya disandarkan pada analisis yuridis normatif. ${ }^{13}$

Ilmu hukum empiris melalui pengolahan terhadap data-data empiris (ex post) memiliki kemampuan untuk meramalkan berbagai kemungkinan yang bakal terjadi. Karya ilmu hukum normatif dimaksudkan untuk mengubah keadaan (ex ante) dan melalui analisis terhadap bahan hukum positif ia menawarkan penyelesaian terhadap problem kemasyarakatan yang konkret. Kedua ilmu yang sangat berbeda karakter ilmiahnya ini tentu dapat memberikan sinergi yang positif untuk kepentingan dan kemajuan masyarakat. Meski demikian, sinergi tersebut baru akan memberikan hasil yang nyata jika orientasi dan karakter masing-masing ilmu tersebut dipahami secara benar dalam satu hubungan kesetaraan yang saling menyapa dan saling memberikan umpan balik. ${ }^{14}$

Ilmu hukum empiris tidak pernah menjadi ilmu hukum normatif, demikian pula sebaliknya ilmu hukum normatif tidak akan pernah menjadi ilmu hukum empiris. Ilmu hukum empiris melakukan kegiatan ilmiah dalam paradigma ilmu

\footnotetext{
${ }^{11}$ Ibid., hlm. 135.

${ }^{12}$ Ibid.

${ }^{13}$ Ibid., hlm. 132.

${ }^{14}$ Ibid., hlm. 132 - 133.
} 
sosial, sedangkan ilmu normatif melakukan kegiatan ilmiahnya dalam paradigma ilmu praktis normologis. Melupakan karakter kedua ilmu tersebut dan berusaha mempersatukannya adalah suatu tindakan yang ceroboh, karena tidak menghargai arah dan kualitas ilmiah yang dihasilkan kedua ilmu tersebut. Memahami dan mamanfaatkan temuan kedua ilmu tersebut untuk kepentingan masyarakat merupakan upaya yang tidak akan pernah berhenti, apa pun rintangannya. ${ }^{15}$

Auguste Comte yang dianggap sebagai peletak dasar positivisme memperkenalkan hukum tiga tahap perkembangan intelektual manusia, yaitu: 1) teologi, 2) metafisika, dan 3) positivis. Ini tercermin dari cara manusia menjelaskan berbagai gejala sosial ekonomi. Manusia pada tahap pertama mengacu kepada hal-hal yang bersifat adikodrati, pada tahap kedua mengacu kepada kekuatankekuatan metafisika, dan pada tahap ketiga mengacu kepada deskripsi dan hukumhukum ilmiah. Positivisme tidak mengakui hal-hal di luar empiris-sensual manusia tersebut. ${ }^{16}$ Bertolak dari hukum-hukum ilmiah, positivisme menekankan bahwa objek yang dikaji harus berupa fakta, dan bahwa kajian harus mengarah kepada kepastian dan kecermatan. Masih menurut Comte, sarana yang dapat dilakukan untuk melakukan kajian ilmiah adalah pengamatan, perbandingan, eksperimen dan metode historis. ${ }^{17}$ Megingat sosiologi dianggap memenuhi hukum tiga tahap dari Comte ini maka hingga saat ini penelitian hukum dari sisi empiris dianggap lebih ilmiah dan mendapat banyak dukungan.

Berbeda dengan positivisme yang bertumpu pada fakta-fakta empiris, rasionalisme menekankan bahwa ilmu berasal dari pemahaman intelektual yang dibangun atas kemampuan argumentasi secara logis. Apa yang terpenting dalam rasionalisme adalah ketajaman dalam pemaknaan empiris. Noeng Muhajir menegaskan bahwa pemahaman intelektual dan kemampuan argumentatif perlu didukung data empiris yang relevan agar produk ilmu yang berlandaskan rasionalisme betul-betul ilmu, bukan fiksi. ${ }^{18}$ Bagi rasionalisme, fakta empiris bukan hanya yang sensual, melainkan ada empiris logis, empiris teoretis, dan empiris etis. Misalnya, ruang angkasa, peninggalan sejarah masa lampau, dan jarak sekian tahun juta cahaya. Semuanya merupakan realitas, tetapi tidak mudah dihayati

\footnotetext{
${ }^{15}$ Ibid., hlm. 133.

${ }^{16}$ Mastuhu (Penelaah), Metodologi Penelitian Agama, PT Raja Grafindo Persada, Jakarta, 2006, hlm. 71.

${ }^{17}$ Ibid., hlm. 72.

${ }^{18}$ Ibid.
} 
secara sensual melainkan dapat dihayati secara teoretis. Karena itu, sekali lagi, rasionalisme mengakui realitas empiris teoretis dan empiris logis. ${ }^{19}$

Inti pemikiran positivisme adalah bahwa apa yang dinamakan ilmu harus bisa dibuktikan secara empiris. Pemikiran ini sebenarnya merupakan embrio dari aliran empirisisme dengan adagium, Experience is the source of all human knowledge (pengalaman adalah sumber ilmu pengetahuan). Metode yang digunakan dalam pemikiran ini didasarkan pada logika induktif. Dalam kaitan dengan ilmu sosial, wacana yang dikembangkan aliran ini bahwa ilmu adalah seluruh informasi yang mengandung pengetahuan dan telah teruji secara benar menurut prosedur sain tentang suatu kejadian di alam empiris. ${ }^{20}$

Penentangan terhadap pemikiran aliran ini muncul dari kalangan rasionalisme dengan jargon yang terkenal di kalangan mereka, The reason is the source of all human knowledge (akal budi manusia merupakan sumber ilmu pengetahuan). Dengan pernyataannya itu maka metode yang digunakan didasarkan pada logika deduktif, logis dan matematis. Pada dasarnya, menurut pandangan rasionalisme, realitas dapat diketahui atau beberapa kebenaran tentang realitas dapat diketahui tanpa bergantung pada pengamatan, pengalaman, dan penggunaan metode empiris. Kebenaran tidak perlu diuji dengan prosedur verifikasi indrawi, tetapi dengan kriteria konsistensi logis. ${ }^{21}$

Kalangan positivisme mengajukan asas verifikasi untuk membuktikan kebenaran ilmiah. Berdasarkan asas ini, suatu putusan ilmiah adalah benar hanya jika keputusan itu dapat diverifikasi secara empiris, medan ujinya adalah fakta atau kenyataan yang dapat diobservasi. Untuk ini metode yang digunakan adalah metode empiris melalui penalaran induksi. Sementara itu, tentang kebenaran, aliran positivisme menganut teori korespondensi yang menyatakan bahwa kebenaran adalah kesesuaian antara putusan atau proposisi dan dunia kenyataan. ${ }^{22}$

Pada sisi lain, aliran rasionalisme mengembangkan teori falsifikasi yang rumit. Inti pemikiran aliran ini bertumpu pada pernyataan bahwa pengetahuan ilmiah harus objektif dan teoretikal dengan analisis akhir yang harus mampu menggambarkan dunia yang dapat diobservasi. Meski tetap mendasarkan pada kebenaran atas dasar teori korespondensi, namun aliran rasionalisme menegaskan bahwa putusan ilmiah

\footnotetext{
19 Ibid.

${ }^{20}$ Johnny Ibrahim, Op. Cit., hlm. $90-91$.

21 Ibid.

${ }^{22}$ Ibid., hlm. 92.
} 
yang sesuai dengan kenyataan yang teramati hanya menghasilkan pengetahuan yang mungkin benar. Karena itu, pengetahuan tersebut hanya dipandang benar sampai dibuktikan sebaliknya. Dengan demikian, aliran ini menolak metode induksi sebagai metode ilmiah dalam memperoleh pengetahuan. Mengingat, kesimpulan umum yang dihasilkan metode induksi bertumpu pada premis-premis partikuler. Metode ilmiah yang tepat menurut aliran ini adalah menggunakan logika deduksi, yakni berdasarkan dalil umum lalu ditarik kesimpulan khusus atau proposisi partikuler. ${ }^{23}$

Bertolak dari pola pikir rasionalisme, variabel penelitian tidak bisa dipahami secara fragmentatif, melainkan harus dipahami secara holistik dalam suatu kerangka nilai dan sistem sosio-kultural, politik dan ekonomi. Karena itu, di antara kritik rasionalisme terhadap positivisme adalah: a. Positivisme cenderung mengabaikan pencarian makna di balik empiris sensual, sehingga hasil-hasil penelitian menjadi kehilangan makna. b. Positivisme terlalu mengunggulkan fakta fragmentatif, sehingga kehilangan konteks sosio-kultural hasil-hasil penelitian. c. Positivisme bersifat reduksionis karena hanya mengakui fakta empiris yang sensual, padahal di samping yang sensual masih terdapat empiris logis, teoretis dan etis. ${ }^{24}$

Dominasi pemikiran aliran positivisme dalam hukum mencapai puncaknya pada paruh pertama abad ke-19 M, seiring munculnya berbagai pengaturan dalam bentuk hukum yang menuntut kepatuhan serta memberi ancaman sanksi agar tercipta masyarakat yang teratur. Struktur masyarakat yang semakin kompleks, tingkat kemajuan ilmu pengetahuan dan teknologi, serta semakin pesatnya perdagangan antarbangsa, membutuhkan para Juris profesional untuk menangani permasalahan hukum. Para Juris yang mendasarkan karyanya pada hukum positivistis-analitis membangun pemikiran rasional dalam memandang hukum sebagai sebuah sistem yang utuh. ${ }^{25}$

Dampak lain pemikiran aliran positivisme dalam hukum adalah berkembangnya ilmu hukum dengan menggunakan format ilmu sosial dalam paradigma ilmu empiris. Para ilmuwan hukum merasa lebih percaya diri apabila menggunakan pendekatan sosial empiris. Dengan menggunakan pendekatan ini, penjelajahan ilmu hukum akan lebih ilmiah karena dapat dikwantifikasi dan memungkinkan digunakannya rumus-rumus ilmu pasti untuk menjamin pembuktian ilmiah dari segi empiris. Pemikiran Comte menginginkan apa yang bersifat sosial dalam

\footnotetext{
${ }^{23}$ Ibid., hlm. $92-93$.

${ }^{24}$ Mastuhu, Op. Cit., hlm. 73.

${ }^{25}$ Johnny Ibrahim, Op. Cit., hlm. 88.
} 
masyarakat dapat diredusir ke dalam dalil-dalil yang pasti sehingga lebih bersifat ilmiah sesuai hukum tiga tahap yang dikembangkannya. ${ }^{26}$

Dengan memasukkan ilmu hukum ke dalam struktur ilmu sosial maka penelitian hukum harus melakukan adaptasi sesuai karakteristik data-data lapangan yang mesti digali, diolah dan dianalisis sedemikian rupa. Fakta-fakta maupun peristiwaperistiwa sosial yang tengah terjadi di masyarakat diolah dengan menggunakan perangkat teori-teori hukum sebagai alat analisisnya. Kemudian temuan berupa konsep-konsep hukum yang dihasilkan secara kwalitatif dapat dikwantifikasi untuk dapat diukur tingkat validasinya.

Mengadopsi metode penelitian ilmu sosial nampaknya memang sulit dihindarkan dalam penelitian hukum lantaran jenis data yang diperlukan memiliki aspek kesamaan berupa fakta-fakta fenomenologi. Tentu saja adopsi ini dilakukan dengan mengawinkan atau sekurang-kurangnya melakukan adaptasi sehingga tidak mengenyampingkan karakteristik penelitian hukum yang empiris sekaligus logis. Khusus dalam penelitian hukum Islam, panduan umum berupa dasar-dasar teori yang bersumberkan wahyu mesti dijadikan alat pembimbing dalam melakukan penelitian. Sebab merupakan bagian karakteristik hukum Islam adalah mempunyai pijakan wahyu baik secara langsung berupa dalil-dalil juz'i yang bersifat mikro maupun tidak langsung berupa dalil-dalil kulli yang makro.

\section{Implikasi Perbedaan Hukum Islam dan Positivisme Barat}

Auguste Comte tidak menggolongkan ilmu hukum ke dalam salah satu kelompok ilmu. Alasan Comte sederhana, ilmu hukum tidak memenuhi kriteria positif dalam hukum tiga tahap yang melandasi penggolongan ilmu versi Comte. Baginya, hukum merupakan bagian dari metafisika yang tidak masuk akal dan tidak mengandung moral. Menurut pandangan sosiologis, filsafat positivisme Comte merupakan penyebab lenyapnya cita rasa hukum untuk selama-lamanya. Namun demikian, pada sisi lain pemikiran Comte memberikan banyak andil pencerahan bagi ilmuwan hukum sesudahnya. Istilah 'positif' dalam lingkup ilmu hukum mulai digunakan secara intens pasca digulirkannya pemikiran filsafat positivisme Comte.

${ }^{26}$ Moch. Koesnoe, Kritik, terbadap Ilmu Hukum, Lembaga Riset dan Pengabdian Masyarakat Fakultas Hukum UII, Yogyakarta, 1981, hlm. 3; Johnny Ibrahim, Ibid., hlm. 89. 
Jika diaplikasikan ke dalam pemikiran tentang hukum, paham positivisme menghendaki dilepaskannya pemikiran metayuridis mengenai hukum sebagaimana dianut oleh para pendukung aliran hukum alam (naturalis) atau aliran hukum kodrat. Karena itu menurut paham positivisme, setiap norma hukum harus eksis dalam alamnya yang objektif sebagai norma-norma yang positif, serta ditegaskan dalam wujud kesepakatan kontrak yang konkret antar warga masyarakat atau wakilwakilnya. Dalam konteks ini, hukum bukan lagi dikonsepsikan sebagai asas-asas moral metayuridis yang abstrak tentang hakikat keadilan, melainkan sesuatu yang telah mengalami positivisasi guna menjamin kepastian mengenai apa yang terbilang hukum. ${ }^{27}$

Meski penggunaan makna positif versi Comte juga memberikan pengaruh terhadap para ilmuwan hukum, namun tidak boleh dilupakan bahwa kata 'positif' juga merupakan asli kata dari kosakata dalam ilmu hukum. Asal kata 'positif' dalam hukum berbeda dengan istilah 'positif' versi Comte. Istilah positif dalam hukum merupakan terjemahan dari ius positum menjadi hukum positif yang mengandung makna hukum yang ditetapkan. Jadi, munculnya istilah ius positum pada zaman hukum romawi jauh lebih awal sebelum pemunculan karya-karya pemikiran Comte. Dalam etimologi latin, positivisme atau positivus mempunyai makna ditetapkan, ditentukan oleh kehendak, dikehendakkan, dan positif. Makna lain dari positivisme adalah meletakkan, yaitu bahwa tindakan manusia itu adil atau tidak, sepenuhnya bergantung pada peraturan atau hukum yang diletakkan atau diberlakukan. ${ }^{28}$

Dalam konteks hukum Islam, apa yang disorot comte sebenarnya mengarah pada elemen hukum ibadah (ritual) yang memang mempunyai watak immutable dan tidak didasarkan pada fakta empiris dan logis. Dalam ranah hukum ibadah unsur akal-budi dan intelektual manusia tidak banyak berperan dalam proses penelusuran makna di balik apa yang tersurat. Sebaliknya, dalam elemen hukum mu'amalah penilaian comte bahwa hukum merupakan bagian dari metafisika yang tidak masuk akal dan tidak memuat unsur moral tidak memiliki relevansinya. Sebab, muatan hukum mu'amalah dalam Islam selain sangat positivistik juga mengapresiasi nilainilai moral dalam membangun pranata sosial berbasiskan ketentuan-ketentuan hukum operasional. Selain itu, akal-budi manusia mempunyai peran cukup signifikan

\footnotetext{
${ }^{27}$ Soetandyo Wignjosoebroto, Hukum Paradigma, Metode dan Dinamika Masalabnya, (editor, Ifdhal Kasim et.al.), Elsa Elsam \& Huma, Jakarta, 2002, hlm. 96; Johnny Ibrahim, Ibid., hlm. 84 - 85.

${ }^{28}$ Lihat Johnny Ibrahim, Ibid., hlm. 85 - 86.
} 
dalam rangkaian kerja istinbath untuk menelorkan ketentuan-ketentuan hukum. Sumber inspirasi dalam hukum mu'amalah selain berupa prinsip-prinsip umum dalam ketentuan wahyu, juga berupa realitas masyarakat dengan aspek perubahan dan pengembangannya yang tak bisa dielakkan.

H.L.A. Hart, seorang Positivist modern berpengaruh di Inggris, membangun tesis tentang positivisme dengan memisahkan secara tegas keterkaitan antara hukum dan moral. Sikap seperti ini sangat berlawanan dengan pandangan aliran hukum alam yang menegaskan bahwa hukum dan moral tidak dapat dipisahkan. Pengaruh Comte terhadap pemikiran Hart tampak pada waktu ia menguraikan gagasan tentang hukum murni yang terpisah dari aspek moral. ${ }^{29}$

Sebagaimana aliran hukum alam, hukum Islam juga tidak memisahkan antara hukum dan moral. Hukum Islam memandang keduanya sebagai satu kesatuan yang tak dapat dipisahkan. Sebagai guide-line atau perangkat aturan, hukum tidak bisa berdiri sendiri dalam pergumulannya dengan masyarakat. Sebaliknya, ia perlu disandingkan dengan komponen lain, yaitu moralitas yang dalam terminologi agama sering disebut tashawwuf atau akhlaq karimah. Dalam kaitan ini adagium yang sering dikemukakan adalah "hukum tanpa moralitas adalah durjana, sementara moralitas tanpa hukum adalah utopia". Dalam ungkapan bahasa arab, adagium yang sering ditekankan para Juris Islam tersebut berbunyi sebagai berikut:

$$
\text { من تفقه ولم يتصوف فقد تفسث ومن تصوف ولم يتفقه فقد تزند ق }
$$

Artinya: Barangsiapa mendalami hukum tapi tidak menekuni tashawwuf (moral) maka sungguh dia menjadi fasiq. Sebaliknya, barangsiapa mempelajari tashawwuf tapi tidak mendalami hukum maka dia telah menjadi zindiq. ${ }^{30}$

Pembedaan normativisme dan empirisme dalam hukum barat nampaknya mempunyai perspektif berbeda dengan klasifikasi hukum Islam. Dalam Islam, hukum secara luas dibagi menjadi dua elemen besar, yaitu figh ibadah (ritual) dan figh mu'amalah (sosial). Apa yang kemudian disebut normatif dalam nomenklatur hukum barat sesunggunya memiliki aspek persamaan dengan hukum Islam dalam pembagian pertama (figh ibadah). Disebut normatif lantaran diktum hukum semacam ini berwatak statis dan tidak dapat berkembang mengikuti irama perubahan yang terjadi di masyarakat. Akan tetapi dari segi sumbernya keduanya memiliki perbedaan

${ }^{29}$ Ibid., hlm. 87.

${ }^{30}$ Abu al-'Abbas Ahmad bin Muhammad bin al-Mahdi, Iqadh al-Humam Syarh Matn al-Hikam, al-Maktabah alSyamilah, Ishdar 3. 28, Juz I, hlm. 2. 
cukup signifikan lantara figh ibadah mengacu pada ketentuan wahyu verbal. Dalam Islam, fiqh ibadah berkaitan dengan tata cara bagaimana seorang hamba melakukan amalan ritual sebagai wujud kehambaan dirinya di hadapan sang pencipta. Ini bisa dilihat dalam praktik ritual keagamaan semisal shalat, puasa, membayar zakat, membaca al-Qur'an dan lain-lain.

Dari wujud kestatisan fiqh ibadah ini kemudian muncul kaidah hukum atau maxim yang sangat populer dalam pemikiran hukum Islam, yaitu:

\section{الله لا يعبد إلا بما شرع}

Artinya: Allah tidak dapat disembah kecuali dengan tata cara yang sudah dianjurkan dalam syari' at. ${ }^{31}$

Dengan mengacu pada kaidah ini maka kita tidak bisa mengkreasi sendiri format ritual keagamaan di luar apa yang sudah ditetapkan dalam diktum-diktum fiqh ibadah. Dalam format ritual shalat, misalnya, kita tidak bisa menambah atau mengurangi jumlah raka'atnya. Begitu juga dalam ibadah haji, kita tidak bisa mengubah rukun-rukunnya, misalnya dengan memindah praktik amalan haji ke tempat lain di luar tanah suci Makkah dan sekitarnya. Karena itu maxim serupa yang juga populer dalam pemikiran hukum Islam mengatakan:

\section{الأصل في العبا دة التحريم إلا ما د ل الد ليل على خلا فه}

Artinya: hukum asal dalam fiqh ibadah adalah haram kecuali ada dalil yang menunjukkan hukum sebaliknya. ${ }^{32}$

Maksudnya, selama belum ada ketentuan baku dalam syari'at menyangkut tata cara ibadah, kita diharamkan membuat tata cara sendiri di luar ketentuan yang sudah digariskan dalam syari'at.

Elemen kedua (mu'amalah) dalam nomennklatur hukum Islam merupakan ketentuan-ketentuan hukum berkaitan dengan persoalan sosial kemasyarakatan. Elemen fiqh yang ini dapat mengalami perubahan sesuai konteks perkembangan masyarakat. Apa yang penting dalam fiqh mu'amalah adalah bagaimana kita mengapresiasi prnsip-prinsip luhur ajaran agama yang dituangkan secara garis besar oleh teks agama. Hal ini seperti nilai-nilai keadialan (al-'adalah), kesetaraan (al-musawat), permusyawaratan (al-syura), saling legawa (al-taradli), tidak terselubung ('adamu algharar), tidak ada pemaksaan ('adamu al-ikrah), dan tidak spekulasi ('adamal-muqamarah).

\footnotetext{
${ }^{31}$ Abu Yasid, Epistemologi Figh: Unsur Substansi, Metodologi dan Aplikasi Ajaran Agama, Ibrahimy Press, Situbondo, 2010, hlm. 136.

${ }^{32}$ Ibid., hlm. 135.
} 
Dengan menegakkan prinsip-prinsip di atas maka fiqh sesungguhnya merupakan gerakan moral dengan menjunjung hak dan kewajiban masing-masing pihak secara proporsional dalam pergaulan hidup sehari-hari.

Selama mengacu pada prinsip-prinsip umum tersebut, ketentuan dalam fiqh mu'amalah tidak memerlukan dalil teks secara terperinci dan mendetail. Kaidah hukum yang sering digunakan dalam menyikapi soal seperti ini adalah,

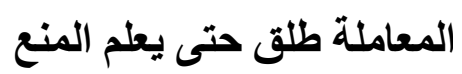

Artinya: fiqh mu'amalah pada dasarnya adalah bebas dilakukan hingga diketahui adanya larangan. ${ }^{33}$

Kaidah lain yang semakna dengan kaidah tadi adalah,

\section{الأصل في المعا ملة الإبا حة إلا ما د ل الا ليل على خلا فه}

Artinya: hukum asal dari fiqh mu'amalah adalah boleh dilakukan kecuali terdapat dalil yang menunjukkan hukum sebaliknya). ${ }^{34}$

Dari kedua kaidah tersebut dapat disimpulkan bahwa tidak seperti hukum ibadah yang statis, hukum mu'amalah mempunyai watak fleksibel dan kompatibel dengan perubahan yang terus terjadi dalam kehidupan bermasyarakat. Kenyataannya, teks agama yang berkaitan dengan fiqh mu' amalah umumnya bersifat mujmal, hanya mengatur persoalan hukum secara garis besarnya saja. Kondisi seperti ini bukannya tanpa disengaja oleh syari' (pembuat syari'at). Sebaliknya, syari' sengaja memberi aturan demikian agar ajaran agama yang berdimensikan sosial dapat bergerak dinamis merespons aneka persoalan yang terus berkembang di tengah masyarakat.

Dalam menyikapi beragam peristiwa hukum di masyarakat, seorang juris mesti mengkajinya dengan menggunakan perangkat istidlal baik berupa teks agama maupun pengamatan terhadap realitas sehingga dapat memunculkan kesimpulan hukum yang mengacu pada prinsip-prinsip luhur ajaran agama. Dengan ungkapan lain, pretensi juris dalam melakukan penggalian hukum adalah bagaimana produk hukum yang dihasilkan dapat mencerminkan nilai-nilai maqashid al-syari'ah (maksud dan tujuan syari'at), yaitu untuk menebar kemaslahatan dan mencegah terjadinya kerusakan (li jalb al-mashalih wa dar'i al-mafasid).

Watak fiqh mu'amalah yang dinamis seperti ini menyebabkan kajian dan penelitian tentang peristiwa-peristiwa hukum di masyarakat menjadi sangat penting

${ }^{33}$ Abu Yasid et.al., Fiqh Politik: Relasi Agama \& Negara Perspek.tif Islam, Ibrahimy Press, Situbondo, 2009, hlm. 17.

${ }^{34}$ Ibid. 
maknanya. Pesatnya perkembangan masyarakat sebagai obyek hukum meniscayakan perlunya membingkai ketentuan hukum dengan menggunakan instrumen baru sesuai konteks perubahan. Karena itu pemilihan metodologi kajian yang sesuai dengan konteks perkembangan masyarakat perlu dilakukan guna mengimplementasikan nilainilai luhur ajaran di tengah kehidupan mereka. Instrumen penelitian hukum, dengan demikian, sesungguhnya bisa mengadopsi penelitian ilmu-ilmu sosial lantaran datadata yang diperlukan berupa fakta alamiah. Penelitian jenis ini kemudian mengalami adaptasi sesuai watak hukum Islam yang memadukan antara pemahaman atau interpretasi terhadap gejala teks wahyu di satu pihak dan fenomena alam berupa fakta dan peristiwa yang terjadi pada masyarakat di pihak lain.

Dalam kenyataannya, hukum Islam dalam elemen mu'amalah mengalami perkembangan cukup pesat dari waktu ke waktu. Jika pada masa-masa awal, figh $m u^{\prime}$ amalah banyak berhubungan dengan jenis-jenis transaksi secara tradisional sesuai realitas masyarakat saat itu, maka sekarang sedemikian berkembang cakupannya sesuai dinamika alat transaksi modern sebagai dampak kemajuan ilmu pengetahuan dan teknologi. Demikian juga dalam hal perkembangan hukum ketatanegaraan, pada masa-masa awal, hukum tata negara belum seberapa berkembang lantaran sistem yang dianut saat itu bersifat monolog dan bertumpu pada aspek kekhalifahan dan kerajaan. Sebaliknya di masa kita sekarang teori ketatanegaraan sedemikian dinamis seiring pesatnya perkembangan negara-negara bangsa (nation states) di belahan dunia, termasuk dunia Islam.

Karena itu tidak mengherankan jika pada masa-masa awal kelahiran hukum Islam, tema-tema kajian yang muncul berkisar pada transaksi jual beli dan yang sejenisnya, hukum perkawinan dengan berbagai implikasinya, serta hukum-hukum pidana Islam (jinayah). Sebaliknya, sekarang, kajian hukum Islam menjangkau tema-tema lebih luas sesuai tingkat perkembangan. Mengingat luasnya wilayah kajian hukum Islam saat ini maka perlu juga ada pemilahan-pemilahan lebih spesifik sehingga paradigma hukum mu'amalah lebih mudah diakses oleh masyarakat. Pemilahan tersebut, misalnya menjadi Fiqh al-Siyasah (hukum politik), Figh al-Daulah (hukum tata negara), Figh alDustur (hukum konstitusi), Figh al-Iqtishad (hukum ekonomi), Figh al-Usrah (hukum keluarga), Figh al-Mar'ah (hukum gender atau perempuan), Al-Figh al-Jina'i (hukum pidana), al-Figh al-Madani (hukum perdata), dan Figh al-Murafa'at (hukum acara).

Dari sudut pendekatan logika yang digunakan, terdapat perspektif berbeda walaupun dalam hal tertentu terdapat sejumlah segi persamaan antara hukum Islam 
dan positivisme barat. Jika positivisme cenderung menggunakan logika induktifempirik, maka dalam hukum Islam pendekatan seperti itu direpresentasikan dalam penyekatan aliran mutakallimin di satu pihak dan aliran ahnaf di pihak lain. Kalangan mutakallimin yang beranggotakan mayoritas juris dalam hukum Islam menggunakan logika deduktif, sementara Ahnaf cenderung memilih pendekatan induktif. Dalam nomenklatur hukum barat, aliran rasionalisme juga berseberangan dengan positivisme dan memilih pendekatan logika deduktif-logis sebagaiman digunakan kalangan mutakallimin dalam hukum Islam. Faktanya, kalangan mutakallimin dan ahnaf lebih mendasarkan pendekatan logika yang digunakan atas teoretisasi hukum Islam. Maksudnya, jika kalangan mutakallimin mendeduksi teori hukum Islam (kaidah ushul fiqh) menjadi postulat-postulat hukum operasional maka kalangan ahnaf sebaliknya, yakni menginduksi kasus hukum yang terjadi di masyarakat menjadi teori-teori hukum yang kemudian dilestarikan oleh pengikutnya hingga sekarang.

Dalam hukum Islam, pendekatan logika digunakan untuk melengkapi dalil-dalil wahyu yang sering mengungkapkan persoalan secara abstrak. Sebab, sejatinya setiap hukum yang melekat pada berbagai peristiwa dan kejadian mempunyai pijakan dalil berupa wahyu. Namun demikian, tidak semua pijakan wahyu dapat tergambarkan secara tersurat dalam lembaran teks al-Qur'an maupun al-Hadith. Sebaliknya, tidak terkira jumlahnya pijakan wahyu yang hanya mengungkapkan persoalan hukum secara tersirat. Atas dasar itu maka dalil wahyu sesungguhnya dapat dibagi menjadi dua jenis, yaitu: a. Dalil juz'i / tafshili , yaitu dalil-dalil terperinci berupa teks wahyu yang menunjukkan hukum-hukum tertentu secara tersurat. Seperti teks wahyu yang dengan lugas menunjukkan hukum wajib melakukan shalat fardu, puasa ramadhan, haram berbuat zina, mencuri, mengalirkan darah sesamanya dan lain-lain. b. Dalil kulli / ijmali, yaitu dalil global yang tidak menunjukkan ketentuan-ketentuan hukum tertentu secara tersurat, tetapi cukup secara tersirat berupa indikator-indikator. Seperti teks hadith yang berbunyi:

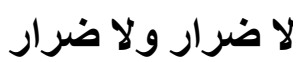
Artinya: Tidak boleh melakukan kemudaratan (HR Imam Ibnu Majah). ${ }^{35}$

Hadith ini tidak secara tersurat menunjukkan hukum haram terhadap peristiwa tertentu. Sebaliknya, tidak sedikit jumlah peristiwa yang ketentuan hukumnya dilandaskan pada hadith ini. Seperti keharaman mengonsumsi narkoba serta perbuatan-perbuatan lain yang dapat mumudaratkan diri sendiri maupun orang lain.

${ }^{35}$ Lihat Ibrahim Muhammad Mahmud al-Hariri, al-Madkhal Ila al-Qawa'id al-Fiqhiyyah al-Kulliyyah, Daru 'Ammar, 
Sungguhpun jenis dalil pertama (juz'i) jelas merupakan acuan hukum, namun bukan berarti jenis dalil kedua ( $k$ ulli) sama sekali tidak bersentuhan dengan proses pembentukan hukum. Ojek pembahasan ushul fiqh sebagai metodologi istinbath hukum adalah justeru berkaitan dengan dalil-dalil yang bersifat kulli ini untuk membuat rumusan kaidah-kaidah yang mempunyai fungsi memudahkan proses istinbath atau penggalian hukum-hukum operasional. Dengan ungkapan lain, kaidahkaidah ushuliyyah yang sangat dibutuhkan Mujtahid dalam kerja akademiknya untuk menggali hukum-hukum operasional bisa disebut juga sebagai dalil kulli karena ia dibangun berdasarkan dalil-dalil wahyu yang mengungkapkan secara umum dan garis besar serta dipadukan dengan unsur logika aksioma.

Karena itu dalil kulli dan $j u z^{\prime} i$ dalam konteks penggalian dan perumusan hukumhukum mempunyai hubungan sangat erat dan hampir tidak bisa dipisahkan satu sama lain. Artinya, dalam rangkaian kerja istinbath al-ahkam (penggalian hukumhukum) selain diperlukan dali-dalil juz'i yang tersurat dalam teks wahyu, juga tidak bisa mengabaikan dalil-dalil kulli baik berupa prinsip-prinsip umum seperti tersirat dalam kandungan teks wahyu maupun kaidah-kaidah ushuliyyah yang sebenarnya juga dikreasi dan diadopsi dari kandungan teks wahyu. Seperti kaidah yang mengatakan bahwa hukum asal dari teks yang berisi perintah adalah wajib; hukum asal dari larangan dalam sebuah teks adalah haram; lafadz umum berlaku keumumannya selama tidak dijumpai pengkhususan dalam teks lain; dan lain-lain.

Di luar proses pembentukannya, hukum sesungguhnya dikreasi bukan untuk dirinya melainkan untuk sesuatu yang lebih luas dan lebih besar di luar dirinya. Pretensi hukum hanyalah untuk menebar keadilan dan kesejahteraan ummat manusia. Lantaran itu, hukum bukanlah institusi yang absolut dan final melainkan bergantung pada manusia sebagai user. Dalam konteks ini, hukum sangat ditentukan oleh faktor manusia dalam melihat dan menggunakannya. Dalam nomenklatur hukum barat, adalah madzhab sociological jurisprudence yang berbagi paham dengan legal realism banyak mengapresiasi hukum dengan pendekatan progresif-dinamis seperti ini. Sementara dalam hukum Islam pendekatan seperti ini direpresentasikan oleh madzhab mashlahi, yakni aliran hukum yang mengedepankan aspek kemaslahatan ketimbang formalitas teks secara legal-prosedural. Dengan pendekatan seperti ini, institusi hukum terus bergerak dinamis membangun dan mengubah dirinya menuju tingkat kesempurnaan yang lebih baik sesuai cita-cita luhurnya menebar keadilan dan kemaslahatan. Hukum, dengan demikian, tidak semata bergerak di atas aras formal-positivistik, melainkan 
mengarah pada aras sosiologis sesuai tingkat perkembangan dan perubahan masyarakat.

\section{Penutup}

Dari hasil penelitian beserta pembahasan yang telah dilakukan menyangkut paradigma pemikiran hukum Islam dan positivisme barat dapat ditarik beberapa kesimpulan sebagai berikut:

Pertama, munculnya paradigma tradisionalisme dan rasionalisme hukum Islam tidak bisa lepas dari kegelisahan akademik menyangkut materi perdebatan jurisprudensi Islam. Terbatasnya jumlah teks wahyu dibanding jumlah peristiwa hukum yang terus mengemuka menyebabkan terjadinya pengkutuban pemikiran dalam jurisprudensi Islam. Kalangan tradisionalisme cenderung mempertahankan tradisi yang sudah melembaga menjadi acuan formal dalam aktivitas penggalian hukum. Madzhab ini dimotori oleh Imam Malik bin Anas yang berpusat di Hijaz. Sebaliknya, kalangan rasionalisme mengedepankan penggunaan akal-budi yang saat itu sering disimplifikasi menjadi qiyas (analogi) dalam rangkaian proses istinbath hukum. Ketokohan madzhab ini sering dinisbatkan pada Imam Abu Hanifah yang berpusat di Baghdad. Al-Syafi'i tampil yang mempunyai kesempatan berinteraksi dengan dua kalangan di atas tampil moderat dengan mengapresiasi tradisi dan rasio secara berimbang dan proporsional.

Kedua, dalam kajian hukum barat ditemukan dua aliran pemikiran, yaitu normativisme (tradisionalisme) yang mendasarkan ketentuan hukum pada pandangan normatif dan positivisme (empirisme) yang selalu bertumpu pada fakta dan pengalaman empirik. Penentangan terhadap kedua aliran ini muncul dari kalangan rasionalisme yang mengatakan bahwa ilmu berasal dari pemahaman intelektual yang dibangun atas kemampuan argumentasi secara logis. Menurut pandangan rasionalisme, realitas dapat diketahui atau beberapa kebenaran tentang realitas dapat diketahui tanpa bergantung pada pengamatan, pengalaman, dan penggunaan metode empiris. Kebenaran tidak perlu diuji dengan prosedur verifikasi indrawi, tetapi dengan kriteria konsistensi logis. Bagi kalangan ini, substansi norma dan pengalaman empirik tidak mempunyai signifikansi apa pun tanpa ketajaman dalam pemaknaan keduanya. Pada ujungnya, artikulasi norma, empirisme dan ketajaman rasio merupakan sesuatu yang niscaya dalam mekanisme pembentukan hukum. Pemahaman intelektual dan kemampuan argumentatif perlu didukung selain oleh norma-norma juga data-data 
empiris yang relevan agar produk hukum betul-betul mempunyai dimensi ilmu, bukan fiksi.

Ketiga, paham positivisme menghendaki dilepaskannya pemikiran metayuridis mengenai hukum. Hukum bukan lagi dikonsepsikan sebagai asas-asas moral metayuridis yang abstrak tentang hakikat keadilan, melainkan sesuatu yang telah mengalami positivisasi guna menjamin kepastian mengenai apa yang terbilang hukum. Dengan demikian, tesis tentang positivisme dengan tegas memisahkan keterkaitan antara hukum dan moral. Sikap seperti ini sangat berlawanan dengan pandangan hukum Islam dan hukum alam yang tidak memisahkan antara hukum dan moral. Hukum Islam memandang keduanya sebagai satu kesatuan yang tak dapat dipisahkan. Sebagai perangkat aturan, hukum tidak bisa berdiri sendiri dalam pergumulannya dengan masyarakat. Sebaliknya, ia perlu disandingkan dengan moralitas yang dalam terminologi agama sering disebut tashawwufatau akhlaq karimah. Perbedaan pandangan seperti ini berimplikasi pada kaitan hukum dengan pranata sosial sebagai subjeknya. Dalam konteks ini, jika hukum bersentuhan dengan moralitas maka substansi hukum tidak bersifat absolut dan final melainkan bergantung pada aspek kemaslahatan sebagai muaranya. Intinya, hukum dikreasi bukan untuk dirinya melainkan untuk menebar keadilan dan kemaslahatan ummat manusia.

Dari hasil temuan serta pembahasannya yang telah disajikan dalam bab sebelumnya, peneliti merasa perlu memberikan saran dan rekomendasi sebagai berikut:

Pertama, memberikan saran dan rekomendasi kepada pakar ilmu jurisprudensi dan para praktisi hukum agar dalam mengembangkan ilmu hukum dapat mengapresiasi materi perdebatan kalangan tradisionalisme dan rasionalisme dalam pemikiran hukum Islam. Hal ini penting kita pertimbangkan untuk mengelaborasi setiap peristiwa hukum sesuai konteksnya. Pemahaman konteks hukum mutlak harus diperhatikan lantaran terbatasnya jumlah teks agama bila dibandingkan jumlah peristiwa hukum yang terus bergerak dinamis. Dengan memperhatikan pola istinbath hukum yang dikembangkan kedua aliran hukum tersebut maka diharapkan pengembangan hukum ke depan tidak beranjak dari nilai-nilai filosofi pembentukannya seperti pernah diperagakan oleh kedua paradigma pemikiran hukum di atas.

Kedua, memberikan saran dan rekomendasi kepada para pakar, praktisi dan pemerhati hukum agar mengapresiasi setiap madzhab pemikiran yang dianggap representatif dalam upaya pengembangan hukum ke arah yang lebih cerah dan 
progresif. Dalam tradisi pemikiran hukum barat, mereka yang perlu dipertimbangkan adalan madzhab normativisme, positivisme dan rasionalisme. Proses artikulasi dari ketiga aliran hukum tersebut perlu dikembangkan karena sejatinya madzhab-madzhab tersebut sesungguhnya saling melengkapi satu sama lain. Ketajaman pemahaman intelektual dan kemampuan argumentatif sebagai ciri dalam madzhab rasionalisme perlu didukung selain oleh norma-norma yang berkembang dalam aliran normativisme juga data-data empiris yang relevan seperti kita temukan dalam madzhab positivisme. Dengan artikulasi simbiosis seperti itu, diharapkan para praktisi dan ilmuan hukum dapat menemukan dan menerapkan produk hukum yang betul-betul mempunyai dimensi ilmu, bukan sekedar fiksi.

Ketiga, memberikan saran dan rekomendasi kepada para ilmuan dan praktisi hukum agar dapat mengambil hikmah dari perdebatan soal keterkaitan hukum dengan moralitas. Sebab, pada intinya, hukum lahir bukan untuk dirinya melainkan untuk tujuan yang sangat besar di luar dirinya, yakni untuk menebar kemaslahatan, kesetaraan dan keadilan di tengah masyarakat. Dengan mengapresiasi perdebatan tersebut maka diharapkan para ilmuan dan praktisi hukum dapat mengimplementasikan temuan hukum sesuai tujuan asasinya, yaitu keamaslahatan. Dalam konteks inilah kemudian unsur moralitas sangat penting ditegakkan secara simultan dengan diktum-diktum hukum secara formal dan prosedural. Penegakan hukum tanpa dibarengi moralitas dikhawatirkan berujung pada tirani dan kedzaliman. Sebaliknya, moralitas tanpa dibarengi ketentuan hukum secara legal-formal bisa mengarah pada utopia belaka.

\section{Daftar Pustaka}

Al-Hariri, Ibrahim Muhammad Mahmud, al-Madkhal Ila al-Qawa'id al-Fiqhiyyah alKulliyyah, Daru 'Ammar, Amman, 1998.

Al-Khinn, Mushthafa Sa'id, Dirasah Tarikhiyyah li al-Figh wa Ushulihi wa al-Ittijahat allati Dhaharat fiha, al-Syirkah al-Muttahidah li al-Tawzi', Damaskus, 1984.

Al-Thabrani, Sulaiman bin Ahmad bin Ayyub (Ishdar 3.28), al-Mu'jam al-Kabir, alMaktabah al-Syamilah, Digital Library.

Arkoun, Mohammed, Rethinking Islam Today, dalam edisi Indonesia, Islam Kontemporer: Menuju Dialog Antar Agama, Pustaka Pelajar, Yogyakarta, 2001.

Bin al-Mahdi, Abu al-'Abbas Ahmad bin Muhammad (Ishdar 3.28), Iqadh al-Humam Syarh Matn al-Hikam, al-Maktabah al-Syamilah, Digital Library.

Coulson, Noel J., Conflicts and Tensions in Islamic Jurisprudence, The University of Chicago Press, USA, 1969. 
Fanani, Ahwan, “Ushul fiqh versus Hermeneutika tentang Pengembangan Pemikiran Hukum Islam Kontemporer", artikel dalam Jurnal Terakreditasi ISLAMICA, Vol. 4, No. 2, Maret, Program Pascasarjana IAIN Sunan Ampel Surabaya, 2010.

Ibrahim, Johnny, Teori \& Metodologi Penelitian Hukum Normatif, Bayumedia Publishing, Malang, 2006.

Koesnoe, Moch., Kritik terhadap Ilmu Hukum, Lembaga Riset dan Pengabdian Masyarakat Fakultas Hukum UII, Yogyakarta, 1981.

Mastuhu, Penelaah, Metodologi Penelitian Agama: Teori \& Praktik, PT Raja Grafindo Persada, Jakarta, 2006.

Shalih, Muhammad Adib, Tafsir al-Nushush fi al-Figh al-Islami, al-Maktab al-Islami, Beirut, 1993.

Sulayman, Abu, 'Abd al-Wahhab Ibrahim, al-Fikr al-Ushuli Dirasah Tahliliyyah Naqdiyyah, Dar al-Syuruq, Jeddah. 1984

Wignjosoebroto, Soetandyo, Hukum, Paradigma, Metode dan Dinamika Masalahnya, editor, Ifdhal Kasim et.al., Elsam \& Huma, Jakarta, 2002.

Yasid, Abu, et.al., Figh Politik: Relasi Agama \& Negara Perspektif Islam, Ibrahimy Press, Situbondo, 2009.

Yasid, Abu, Epistemologi Fiqh: Unsur Substansi, Metodologi dan Aplikasi Ajaran Agama, Ibrahimy Press, Situbondo, 2010.

, "Memahami Jurisprudensi Islam sebagai Mekanisme Istinbath Hukum", artikel dalam Jurnal Terakreditasi AKADEMIKA, Vol. 17 No. 1, September, Program Pascasarjana IAIN Sunan Ampel Surabaya, 2005. 